\title{
The Adjunctive Impact of Counselling in Management of Dermatological Patients: Tertiary Hospital Experience
}

\author{
Ukonu A. B. ${ }^{1} \&$ Ezechukwu A. ${ }^{1}$ \\ ${ }^{1}$ University of Abuja Teaching Hospital, Gwagwalada, FCT Abuja, Nigeria \\ Correspondence: Ukonu A. B, University of Abuja Teaching Hospital, Gwagwalada, FCT Abuja, Nigeria. Tel: \\ 234-803-786-6885. E-mail: bobify@yahoo.com
}

Received: August 9, 2014

doi:10.5539/ijps.v6n4p143
Accepted: September 12, $2014 \quad$ Online Published: November 22, 2014

URL: http://dx.doi.org/10.5539/ijps.v6n4p143

\begin{abstract}
Background

The skin as one of the largest organs in the body mirrors our emotion. Exhaustive inquiry of a dermatology patients' life experience might help to provide insight and understanding to coping and the need for psychological counselling which might help in long term remission of such dermatoses.
\end{abstract}

\section{Methods and Materials}

This interventional study was carried out on newly diagnosed dermatology subjects from September 2012 to February 2014. Within this period, subjects who met the inclusion criteria for the study were recruited into the study by the researchers. The diagnoses of the skin deramtoses were made and some confirmed by histology were necessary.

Each of the subjects was administered a self-evaluation structured questionnaire after thorough explanation and consent to participate in the study was obtained. Their psychological morbidity was noted and thirty (30) minutes to Sixty (60) minutes counselling session conducted for each subject.

\section{Results}

A total number of 2,340 dermatological patients were seen out of which 930 were newly diagnosed dermatological cases. Two hundred and forty six (246) who met the inclusion criteria for the study were recruited. These comprised $155(63.0 \%)$ females and 91 (37.0\%) males. Their age ranges from 15years to $70 y e a r s$ with a mean age and standard deviation of 31.6years \pm 11.2 respectively. Subjects who were students with higher educational degree suffered more psychological morbidity or distress. However, there was statistically significant reduction on the impact of their psychological morbidity after few sessions of counselling which comprised psychoanalytical psychotherapy and cognitive behavioural therapy.

In conclusion, there was a significant psychological morbidity among dermatological patients. Imperatively, a well articulated and integrated psychotherapy and cognitive behavioural therapy would be of immense benefits to dermatology patients apart from administration and usage of drugs.

Keywords: skin dermatoses, psychological morbidity, impact of counselling

\section{Introduction}

People with dermatological illnesses are left feeling less important as individuals. They also tend to be highly sensitive to social significance of their actions and appearances, anticipating rejection by others with some degree of embarrassment and shame (Kellett \& Gilbert, 2001). It is therefore not surprising that majority or significant number of such dermatological patients due to their appearance alteration perception do have psychological morbidity. However, little attention has been paid to them and ways of attending to these integral components of the state of their disease has also been neglected (Fortune et al., 2000; Koblenzer, 1983); the link between dermatological and psychological problems has long been established in most literatures (Koblenzer, 1983; Papadopoulos, 1999a).

The skin is a complex system that is made up of glands, blood vessels, nerves and muscle elements, many of which are controlled by the autonomic nervous system and can be influenced by psychological stimuli 
(Papadopoulos, 1999b). These have the capacity to cause autonomic arousal and are capable of affecting the skin and the development of various skin disorders (Van Moffaert, 1992).

Psychological factors have long been associated with the onset, maintenance and even exacerbation of dermatological disorders (Cole, Roth, \& Sachs, 1998; Koo, 1995; Buljan \& Situm, 2005). Just like other parts of the world, common skin dermatoses in our environment includes, dermatitis, acne vulgaris, Lichen planus, viral and fungi infection (Folks \& Kinney, 1992; Alebiosu, 2002).

This study would aim at identifying most skin dermatoses with high psychological issues and the level of impact of counselling in addressing such dermatoses. The knowledge of such would help not only to effectively manage such patient but to reemphasize a multidisciplinary collaboration between the dermatologist, clinical psychologist and the psychiatrist.

\section{Materials and Method}

The study was carried out in the dermatology unit of the University of Abuja Teaching hospital between September 2012 and February 2014. Dermatology referrals come from within the hospital, private and government owned hospitals in Abuja and sister states viz. Kogi; Niger, Nasarawa, Plateau, Benue and Kaduna. Study subjects were recruited from newly diagnosed dermatological patients through a simple random method bearing in mind the following criteria:

Subjects must be/have:

i) Fifteen years and above

ii) Minimum of primary school education

iii) Ability to understand and write English language and;

iv) Consent to participate in the study

Exclusion criteria where:

i) Patients less than fifteen years

ii) Nil formal education

iii) Comorbid conditions with high psychological impact like Diabetes, retroviral disease, cancers, Haemoglobinopathies

iv) Those who declined to participate in the study.

Appropriate sociodermographic data was obtained with diagnosis of the skin dermatoses made and histological confirmation obtained were necessary. Furthermore, they were assessed with self-evaluation questionnaire on State-Trait Anxiety Index (STAI) score which were filled and, total scores noted during their first visit. The State-Trait Anxiety Index (STAI) score contains 20 self- descriptive statements to which subjects responded by noting the intensity of their reaction on a 4 - point scale. The instruction is to report the present feelings, the state of anxiety is revealed.

Scoring: separate scores ranging from 0-80, are calculated for the two scales. A-State and A-trait. The scale produces a measure of anxiety more independent of depression (Spielberger, Gorrsuch, \& Lushere, 1987).

Further sample questionings to evaluate subjects who had pervasive mood or loss of interest in daily activities were identified and regarded as being depressed.

Each subject underwent 30-60 minutes counselling session which includes psychoanalytical psychotherapy and cognitive behavioural therapy concerning not only their dermatological problem but also the identifiable psychological morbidity. Subjects that did not come back after the first counselling session served as the control group. For each clinic visit the process was repeated and scores generated were keyed into and analyzed with IBM SPSS version 19.0. Statistical measures used include frequencies, analysis of variances, independent $t$-test, paired t-test for subjects that came for second and third visit, and correlations of the counselling sessions of the various visit to determine the impact of the psychological intervention.

\section{Results}

During the study period a total of two hundred and forty six (246) $26.2 \%$ who met the inclusion criteria were enrolled from the nine hundred and thirty six new dermatological patients seen. These comprised one hundred and fifty five (155) (63.0\%) females and ninety-one (91) (37.0\%) males. The age ranges from 15 years to 70 years with a mean age of 31.6 years and standard deviation $(\mathrm{SD}) \pm 11.2$ respectively. The female to male ratio was 1:7:1 and dermatological disorder with high psychological morbidity includes pilosebacous disorders 
(among which are inflammatory and non inflammatory acne vulgaris) 51 (20.7\%), Eczematous dermatitis (with atopic dermatitis topping the group) 50 (20.3\%), Papulosquamous disorders (Lichen planus \& Psoriasis) 30 (12.2\%), chronic urticaria 18 (7.3\%), Viral infection (facial \& genital warts) $15(6.1 \%)$, connective tissue disease (e.g. discoid lupus erythematosis) 7 (2.8\%) respectively.

Subjects who were students with higher educational degree suffered more psychological symptoms ranging from anxiety, depression social phobia respectively.

Table 1. Mean score of the different skin dermatoses and their frequencies

\begin{tabular}{llll}
\hline Various Skin Dermatoses & Mean (SD) & Frequency & \% \\
\hline Eczematous Dermatitis & $51.8(7.6)$ & 50 & 20.3 \\
Hair Disorder & $55.2(11.3)$ & 6 & 2.4 \\
Palpulosquamous Disorder & $50.6(6.3)$ & 30 & 12.2 \\
Viral Infection & $49.3(6.7)$ & 15 & 6.1 \\
Pigmentary Disorder & $47.0(3.5)$ & 4 & 1.6 \\
Pilosebaceous & $49.0(6.6)$ & 51 & 20.7 \\
Chronic Urticaria & $52.8(8.7)$ & 18 & 7.3 \\
Adverse Drug Eruptions & $51.6(4.8)$ & 5 & 2.0 \\
Connective Tissue Disorder & $49.4(5.0)$ & 7 & 2.8 \\
Fungi Infections & $49.0(12.4)$ & 6 & 2.4 \\
Genodermatoses & $50.0(0)$ & 2 & 0.8 \\
Benign Neoplastic Skin Disorder & $52.0(6.2)$ & 5 & 2.0 \\
Bullous Disorder & $47.3(10.2)$ & 3 & 1.2 \\
Generalized Pruritis & $47.9(9.3)$ & 7 & 2.8 \\
Follicular Hyperkeratosis & $48.0(9.1)$ & 4 & 1.6 \\
Eruptive Vellus Hair Disorder & $54.0(5.6)$ & 3 & 1.2 \\
Lymphedema & $52.0(7.2)$ & 3 & 1.2 \\
Others & $49.3(6.9)$ & 15 & 6.1 \\
Hansen's Disease & $54.5(9.7)$ & 4 & 1.6 \\
Combination of two skin diseases & $47.7(4.1)$ & 6 & 2.4 \\
Papular Pruritic Urticaria & $47.0(9.9)$ & 2 & 0.8 \\
& $50.4(7.3)$ & 246 & 100 \\
\hline
\end{tabular}

Table 1 above shows the frequency distribution of the different skin dermatoses in the study and their respective mean score and standard deviation.

Table 2 below depicts the socio demographic factors and their mean scores at the first visit, second visit and the third visit respectively. Independent $t$ test was conducted to ascertain if there were reduction in the mean scores of males after the first and second visit separately, female separately, also married and singles separately and other socio demographic. There was statistically significant reduction in their mean after the first visit and second visit with $t$ test $p<0.05$, except for those with primary education where there was no statistically significant reduction in their mean score after the second visit with $\mathrm{p}>0.05$.

Analysis of variance ANOVA was conducted to test if there were statistically significant differences in the different groups. There were no statistically significant differences in the mean score among the different age groups, educational status, marital status and gender at the three visits with exception of the second visit where there was statistically significant difference in the mean score of males and female. 
Table 2. Socio-demographic factors and their mean score at first visit, second visit and third visit respectively

\begin{tabular}{|c|c|c|c|c|c|c|c|c|c|c|c|c|c|c|c|}
\hline \multirow[t]{2}{*}{ Variables } & \multicolumn{3}{|c|}{$\begin{array}{l}1^{\text {st }} \text { visit mean score } \\
(\mathrm{n}=\mathbf{2 4 6})\end{array}$} & \multicolumn{3}{|c|}{$\begin{array}{l}2^{\text {nd }} \text { Visit mean Score } \\
(n=173)\end{array}$} & \multicolumn{2}{|c|}{$\begin{array}{l}3^{\text {rd }} \text { Visit mean } \\
(\mathrm{n}=63)\end{array}$} & score & \multicolumn{3}{|c|}{$\begin{array}{l}\text { t-test for } 1^{\text {st }} \text { visit and second } \\
\text { visit mean score }\end{array}$} & \multicolumn{3}{|c|}{$\begin{array}{l}\text { t-test for } 2^{\text {nd }} \text { visit and } 3 \text { rd } \\
\text { visit mean score }\end{array}$} \\
\hline & $\mathbf{N}$ & Mean & (SD) & $\mathbf{N}$ & Mean & (SD) & $\mathbf{N}$ & Mean & (SD) & t & df & $\mathbf{p}$ & $\mathbf{t}$ & df & $\mathbf{p}$ \\
\hline \multicolumn{16}{|l|}{ Sex: } \\
\hline Male & 91 & 50.3 & $(6.9)$ & 56 & 43.7 & (6.7) & 24 & 38.5 & (6.4) & 5.69 & 145 & $0.0001^{*}$ & 3.22 & 78 & $0.0019^{*}$ \\
\hline Female & 155 & 50.5 & $(7.5)$ & 117 & 41.3 & (6.3) & 39 & 35.0 & (7.8) & 10.72 & 270 & $0.0001^{*}$ & 5.08 & 154 & $0.0001^{*}$ \\
\hline $\mathbf{F}, \mathbf{P}$ & 0.017 & 0.898 & & 5.17 & $0.024^{*}$ & & 3.62 & 0.06 & & & & & & & \\
\hline \multicolumn{16}{|l|}{ Age Group: } \\
\hline 15-34years & 165 & 50.3 & (7.6) & 117 & 42.0 & $(6.2)$ & 43 & 36.3 & (7.9) & 9.74 & 280 & $0.0001 * *$ & 4.78 & 158 & $0.0001^{* *}$ \\
\hline 35-54years & 69 & 50.4 & (6.6) & 46 & 41.6 & (7.4) & 16 & 35.4 & (6.9) & 6.67 & 113 & $0.0001^{* *}$ & 5.05 & 60 & $0.0001 * *$ \\
\hline$\geq$ 55years & 12 & 52.0 & (6.7) & 10 & 46.0 & (4.5) & 4 & 40.3 & (3.3) & 2.71 & 60 & $0.0088^{*}$ & 2.28 & 12 & $0.042 *$ \\
\hline $\mathbf{F}, \mathbf{P}$ & 0.296 & 0.744 & & 1.98 & 0.141 & & 0.67 & 0.52 & & & & & & & \\
\hline \multicolumn{16}{|l|}{ Educational } \\
\hline \multicolumn{16}{|l|}{ Status: } \\
\hline Primary & 17 & 53.2 & (7.4) & 11 & 41.2 & (5.4) & 4 & 38.5 & (4.4) & 4.63 & 26 & $0.0001^{* *}$ & 0.89 & 13 & 0.389 \\
\hline Secondary & 77 & 51.3 & (7.2) & 57 & 43.0 & (6.3) & 16 & 34.8 & $(8.2)$ & 6.95 & 132 & $0.0001^{* *}$ & 4.30 & 71 & $0.0001^{* *}$ \\
\hline Tertiary & 152 & 49.7 & (7.2) & 105 & 41.4 & (6.7) & 43 & 36.7 & (7.4) & 9.01 & 255 & $0.0001^{* *}$ & 3.99 & 146 & $0.0001^{* *}$ \\
\hline $\mathbf{F}, \mathbf{P}$ & 2.598 & 0.077 & & 0.75 & 0.476 & & 0.58 & 0.56 & & & & & & & \\
\hline \multicolumn{16}{|l|}{ Marital } \\
\hline \multicolumn{16}{|l|}{ Status: } \\
\hline Single & 137 & 50.5 & (7.4) & 94 & 41.9 & (6.3) & 35 & 35.5 & (7.9) & 9.21 & 229 & $0.0001^{* *}$ & 4.78 & 127 & $0.0001 * *$ \\
\hline Married & 109 & 50.3 & (6.8) & 79 & 42.4 & (6.8) & 28 & 37.4 & (6.8) & 7.86 & 186 & $0.0001^{* *}$ & 3.34 & 105 & $0.0011^{*}$ \\
\hline $\mathbf{F}, \mathbf{P}$ & 0.029 & 0.866 & & 0.21 & 0.645 & & 1.06 & 0.31 & & & & & & & \\
\hline
\end{tabular}

SD -Standard deviation

$\mathrm{P}$ values marked $* *$ - Highly statistically significant

* - Statistically significant

$\mathrm{F}$ is the Analysis of Variance (ANOVA) value \& $\mathrm{df}$ is the degree of freedom

It can be deduced from table 2 above that $61.5 \%$ males, $75.5 \%$ females, $68.8 \%$ singles, $72.5 \%$ married persons, $64.7 \%$ subjects with primary education, $74.0 \%$ subjects with secondary education and $69.1 \%$ subjects with tertiary education came back for the second session respectively; while $42.9 \%$ males, $33.3 \%$ females, $37.2 \%$ singles, $35.4 \%$ married persons, $36.4 \%$ subjects with primary education, $28.1 \%$ subjects with secondary education and $40.9 \%$ subjects with tertiary education came back for the third session respectively. There were statistically significant reductions per each counselling visit with better clinical improvement on the dermatology as summarized on table 2 above. 
Table 3. The mean score of dermatological diseases with high Psychological distress at the first visit by their gender

\begin{tabular}{|c|c|c|c|c|c|c|c|}
\hline \multirow[t]{2}{*}{ Skin disorder } & \multicolumn{2}{|c|}{ Male } & \multicolumn{2}{|c|}{ Female } & \multirow[b]{2}{*}{$T$ test } & \multirow[b]{2}{*}{ df } & \multirow[b]{2}{*}{$\mathbf{p}$} \\
\hline & $\begin{array}{l}\text { Mean } \\
\mathbf{N}\end{array}$ & (SD) & $\begin{array}{l}\text { Mean } \\
\mathbf{N}\end{array}$ & (SD) & & & \\
\hline Pilosebacous disorder & $49.8(6.8)$ & 20 & $48.6(6.6)$ & 31 & 0.627 & 49 & 0.534 \\
\hline Eczematous dermatitis & $50.2(6.9)$ & 10 & $52.3(7.7)$ & 40 & 0.786 & 48 & 0.436 \\
\hline Papulosquamous disorder & $50.5(5.6)$ & 13 & $50.7(6.9)$ & 17 & 0.085 & 28 & 0.933 \\
\hline Chronic urticaria & $53.1(8.4)$ & 7 & $52.6(9.2)$ & 11 & 0.116 & 16 & 0.909 \\
\hline Viral infection & $48.6(6.8)$ & 8 & $50.1(7.1)$ & 7 & 0.418 & 13 & 0.683 \\
\hline Hair disorder & $58.5(14.8)$ & 2 & $53.5(11.4)$ & 4 & 0.468 & 4 & 0.664 \\
\hline Fungi infection & $59.0(12.7)$ & 2 & $44.0(10.2)$ & 4 & 1.592 & 4 & 0.187 \\
\hline
\end{tabular}

The table 3 above shows the mean score on STAI of subjects with high psychological distress at their first visit by gender. Mean score of female subjects diagnosed of Pilosebacous disorder, Chronic urticaria, and hair disorder were lower than that of their men counterpart. Seven of the subjects diagnosed of connective tissue disorder and generalized pruritis each were all females whereas the three with Eruptive hair disorder were all male subjects. However, the mean differences of male and female subject with different skin disorder were not statistically significant at the first visit.

Table 4. Correlation and t test for subjects that came back for the second counselling session

\begin{tabular}{|c|c|c|c|c|c|c|c|}
\hline \multirow[t]{2}{*}{ Skin Dermatoses } & \multirow[t]{2}{*}{ Frequency } & \multirow{2}{*}{$\begin{array}{l}\text { First visit mean } \\
\text { score } \\
\text { Mean (SD) }\end{array}$} & \multirow{2}{*}{$\begin{array}{l}\text { Second visit mean } \\
\text { score } \\
\text { Mean (SD) }\end{array}$} & \multicolumn{2}{|c|}{ Correlation (r) } & \multicolumn{2}{|c|}{ Paired t-test } \\
\hline & & & & $\mathbf{r}$ & p value & $\mathbf{t}$ & $\mathbf{p}$ \\
\hline Pilosebacous & 42 & $49.2(6.6)$ & $41.4(5.0)$ & 0.744 & $0.0001 * *$ & 11.5 & $0.0001 * *$ \\
\hline Eczematous Dermatitis & 40 & $52.3(7.1)$ & $42.3(6.7)$ & 0.531 & $0.0001 * *$ & 9.46 & $0.0001 * *$ \\
\hline Papulosquamous disorder & 22 & $49.9(6.4)$ & $42.1(8.4)$ & 0.631 & $0.002 *$ & 5.54 & $0.0001 * *$ \\
\hline Chronic urticaria & 14 & $53.6(8.5)$ & $42.9(6.2)$ & 0.401 & 0.151 & 4.82 & $0.0001 * *$ \\
\hline Viral Infection & 8 & $50.8(6.6)$ & $43.3(5.8)$ & 0.545 & 0.163 & 3.58 & $0.009 *$ \\
\hline Connective Tissue disorder & 5 & $50.8(5.2)$ & $42.6(6.2)$ & 0.643 & 0.242 & 3.73 & $0.02 *$ \\
\hline Hair disorder & 4 & $59.8(11.3)$ & $46.3(10.3)$ & 0.980 & $0.02 *$ & 11.3 & $0.001 * *$ \\
\hline Fungi disorder & 2 & $46.0(17.0)$ & $32.5(3.5)$ & 1.000 & $0.0001 * *$ & 1.42 & 0.390 \\
\hline Generalized pruritus & 4 & $49.3(11.0)$ & $41.3(3.1)$ & 0.977 & $0.023 *$ & 2.9 & 0.07 \\
\hline
\end{tabular}

SD: Standard deviation

$P$ value marked*: Statistically significant

Out of the 246 subjects who were enrolled into the study only one hundred and seventy three (173) $70.3 \%$ came for a second counselling session and sixty three (63) $36.4 \%$ of the 173 showed up for a third counselling session. There were statistically significant reductions in the mean score per each counselling session with better clinical improvement on the dermatological disorder. Although there was reduction in the mean score of subjects diagnosed with fungi disorder and generalized pruritus, ( $t$ test value of 1.42 and 2.9 respectively) was not statistically significant at $p>0.05$. Furthermore, high correlations per each counselling session in Pilosebacous, eczematous dermatitis, papulosquamous disorder, hair disorder, fungi disorder and generalized pruritus were observed and they were statistically significant as shown in table 4 above. 
Table 5. Mean scores of subjects with high psychological morbidity at different counselling sessions

\begin{tabular}{|c|c|c|c|c|c|c|c|c|c|c|c|}
\hline \multirow[t]{2}{*}{ Skin Dermatoses } & \multirow{2}{*}{$\begin{array}{l}\begin{array}{l}\text { Mean Score } \\
\text { on } 1^{\text {st }} \text { visit }\end{array} \\
\text { Mean (SD) }\end{array}$} & \multirow{2}{*}{$\begin{array}{l}\begin{array}{l}\text { Mean Score } \\
\text { on } 2^{\text {nd }} \text { visit }\end{array} \\
\text { Mean (SD) }\end{array}$} & \multirow{2}{*}{$\begin{array}{l}\begin{array}{l}\text { Mean Score } \\
\text { on } 3^{\text {rd }} \text { visit }\end{array} \\
\text { Mean (SD) }\end{array}$} & \multicolumn{2}{|c|}{$\begin{array}{l}\text { Correlation of } 1^{\text {st }} \\
\& 2^{\text {nd }} \text { Visit }\end{array}$} & \multicolumn{2}{|c|}{$\begin{array}{l}\text { Correlation of } 2^{\text {nd }} \\
\& \text { 3rdVisit }\end{array}$} & \multicolumn{2}{|c|}{$\begin{array}{l}\text { Paired t test } \\
\left(1^{\text {st }} \& 2^{\text {nd }} V \text { isit }\right)\end{array}$} & \multicolumn{2}{|c|}{$\begin{array}{l}\text { Paired } t \text { test }\left(2^{\text {nd }}\right. \\
\left.\& 3^{\text {rd }} V \text { isit }\right)\end{array}$} \\
\hline & & & & $\mathbf{r}$ & $\mathbf{p}$ & $\mathbf{r}$ & $\mathbf{p}$ & $\mathbf{t}$ & $\mathbf{p}$ & $\mathbf{t}$ & $\mathbf{p}$ \\
\hline Pilosebacous & $52.2(8.9)$ & $43.8(6.5)$ & $38.0(7.9)$ & 0.841 & $0.0001 *$ & 0.900 & $0.0001 *$ & 6.36 & $0.0001 *$ & 5.96 & $0.0001^{*}$ \\
\hline $\begin{array}{l}\text { Eczematous } \\
\text { Dermatitis }\end{array}$ & $56.6(7.4)$ & $44.9(6.6)$ & $30.0(14.1)$ & 0.664 & 0.051 & 0.942 & $0.0001 *$ & 5.95 & $0.0001 *$ & 9.29 & $0.0001^{*}$ \\
\hline Chronic urticaria & $55.9(7.7)$ & $44.6(6.5)$ & $35.9(6.8)$ & 0.228 & 0.527 & 0.704 & $0.023^{*}$ & 4.03 & $0.003^{*}$ & 5.35 & $0.0001^{*}$ \\
\hline Viral Infection & $52.0(8.9)$ & $44.0(5.9)$ & $30.8(7.9)$ & 0.585 & 0.445 & -0.34 & 0.656 & 2.21 & 0.115 & 2.334 & 0.102 \\
\hline $\begin{array}{l}\text { Connective Tissue } \\
\text { disorder }\end{array}$ & $48.0(0.1)$ & $41.5(9.2)$ & $29.0(12.7)$ & - & & 1.000 & $0.0001 *$ & 1.00 & 0.500 & 5.00 & 0.126 \\
\hline
\end{tabular}

SD: Standard deviation

$P$ value Marked*: Statistically significant

Figure 1 below and table 5 above illustrates the mean scores of subjects with high psychological morbidity at their different counselling sessions. Sixty three (63) of the subjects deemed it fit to come back for another counselling session after the second visit. Nonetheless, there were high positive correlations between each counselling session. It can be observed from table 5 above that there were better positive statistically significant correlations between the second and the third counselling session except for viral infection with a negative correlation. Most of the skin dermatoses had statistically significant reduction in their mean scores after each counselling session.

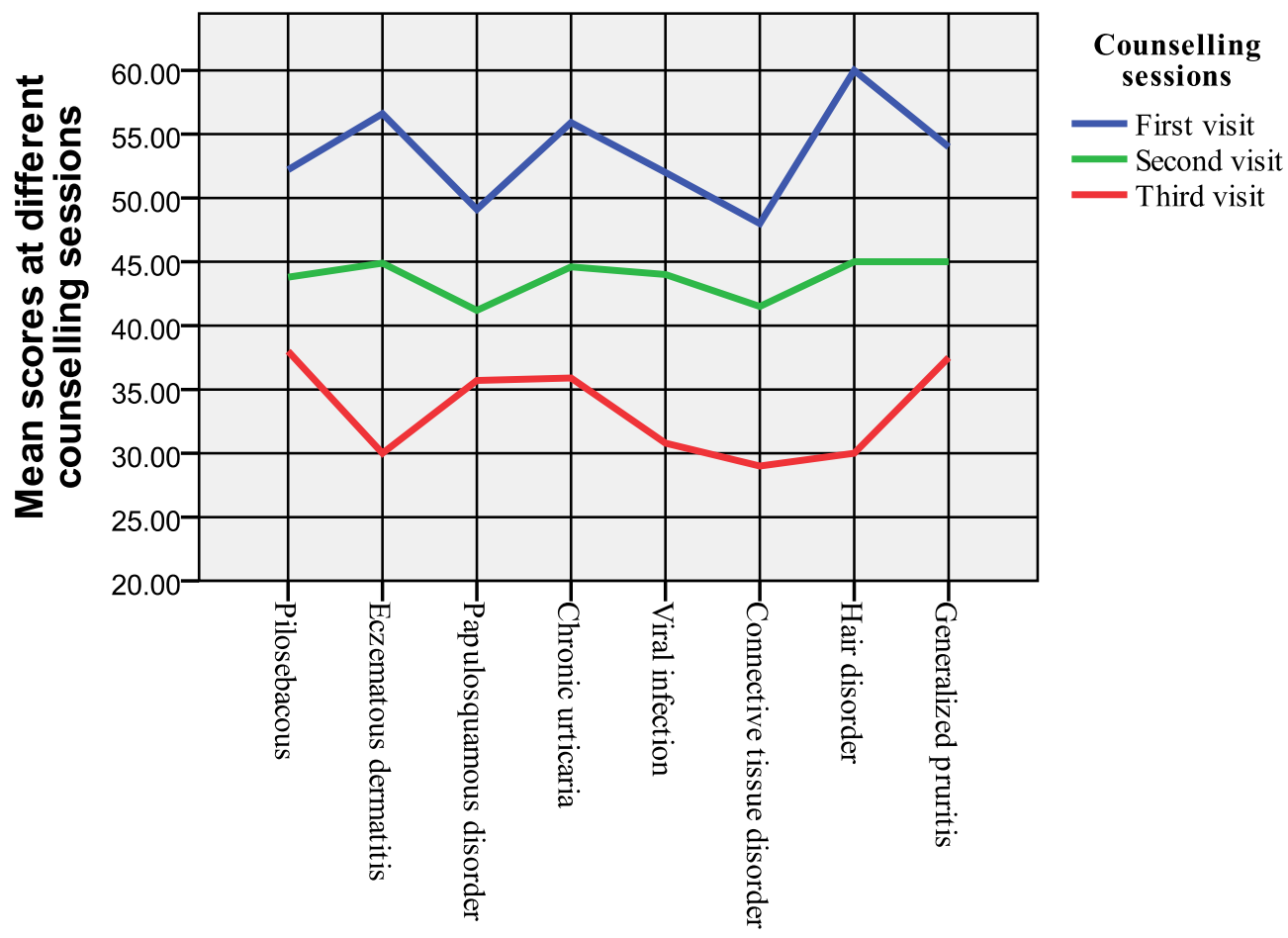

Skin dermatoses

Figure 1. Mean scores of subjects with high psychological morbidity at different counselling sessions 
Table 6. Comparison of Mean scores and socio demographic characteristics of both control and subject with high psychological distress at the first counselling session

\begin{tabular}{|c|c|c|c|c|c|c|c|c|c|}
\hline \multirow[t]{2}{*}{ Variable } & \multicolumn{3}{|c|}{ Control } & \multicolumn{3}{|c|}{ Subject } & \multirow[b]{2}{*}{$\mathbf{t}$} & \multirow[b]{2}{*}{ df } & \multirow[b]{2}{*}{$\mathbf{p}$} \\
\hline & $\mathbf{N}$ & Mean & (SD) & $\mathbf{N}$ & Mean & (SD) & & & \\
\hline \multicolumn{10}{|l|}{ SEX } \\
\hline Male & 35 & 48.7 & $(7.5)$ & 56 & 51.4 & $(6.2)$ & 1.863 & 89 & 0.065 \\
\hline Female & 38 & 49.4 & $(7.2)$ & 117 & 50.8 & $(7.7)$ & 0.989 & 153 & 0.324 \\
\hline \multicolumn{10}{|l|}{ MARITAL STATUS } \\
\hline Single & 43 & 48.8 & (7.7) & 94 & 51.3 & 7.5 & 1.764 & 135 & 0.081 \\
\hline Married & 30 & 49.4 & $(6.7)$ & 79 & 50.0 & 6.9 & 0.409 & 107 & 0.634 \\
\hline \multicolumn{10}{|l|}{ EDUCATIONAL STATUS } \\
\hline Primary & 6 & 54.0 & $(6.0)$ & 11 & 52.7 & $(8.3)$ & 0.337 & 15 & 0.241 \\
\hline Secondary & 20 & 49.9 & $(8.5)$ & 57 & 51.8 & $(6.7)$ & 1.016 & 75 & 0.513 \\
\hline Tertiary & 47 & 48.0 & $(6.7)$ & 105 & 50.4 & (7.4) & 1.901 & 150 & 0.059 \\
\hline \multicolumn{10}{|l|}{ AGE GROUP } \\
\hline 15-34years & 48 & 48.8 & (7.6) & 117 & 51.0 & (7.6) & 1.689 & 163 & 0.093 \\
\hline 35-54years & 23 & 49.4 & $(6.9)$ & 46 & 50.9 & $(6.5)$ & 0.885 & 67 & 0.379 \\
\hline$\geq 55$ years & 2 & 52.0 & $(9.9)$ & 10 & 52.0 & $(6.7)$ & 0.000 & 10 & 1.000 \\
\hline \multicolumn{10}{|l|}{ SKIN DERMATOSES } \\
\hline Eczematous disorder & 10 & 50.1 & $(9.5)$ & 40 & 52.3 & $(7.1)$ & 0.818 & 48 & 0.418 \\
\hline Papulosquamous disorder & 8 & 52.6 & $(2.8)$ & 22 & 49.9 & $(6.4)$ & 1.144 & 28 & 0.262 \\
\hline Viral Infection & 7 & 47.7 & $(7.0)$ & 8 & 50.8 & $(6.6)$ & 0.883 & 13 & 0.394 \\
\hline Pilosebacous disorder & 9 & 48.1 & (7.8) & 42 & 49.2 & $(6.6)$ & 0.449 & 49 & 0.655 \\
\hline Chronic urticaria & 4 & 50.3 & $(10.0)$ & 14 & 53.6 & $(8.5)$ & 0.661 & 16 & 0.518 \\
\hline Fungi infection & 4 & 50.5 & $(12.4)$ & 2 & 46.0 & $(17.0)$ & 0.379 & 4 & 0.724 \\
\hline Overall Mean at first visit & 73 & 49.0 & (7.3) & 173 & 51.0 & $(7.2)$ & 2.002 & 244 & $0.046 *$ \\
\hline
\end{tabular}

SD: Standard deviation

P value marked*: Statistically significant

In Table 6 above, the seventy three (73) 29.7\% that did not come back for another counselling session were used as the control group, to determine if there were any significant difference in those who came back and those who did not. It was observed that the overall mean of the 173 who came back for the second counselling session was higher than the mean of the 73 who did not come back and it was statistically significant and $p<0.05$.

\section{Discussion}

Majority of dermatological diseases do not threaten life rather, they have negative impact on the quality of life in a good number of patients, psychological and social distractions are observed. Many patients facing social isolation adapt to this situation, however in some patients, serious adaptation disorder may arise in addition to these psychological problems such as depression, anxiety and social phobia may develop (Koblenzer, 1983).

Literature has documented psychological intervention for a number of cutanoeus conditions such as vitiligo, psoriasis, acne vulgaris and, atopic dermatitis, which have been suggested to be as effective for each of these types of disorder as classical medical therapeutic process (Van Moffaert, 1992; Higgins \& Du Viver, 1994). In our study we found positive correlation between psychological intervention (psychoanalytical psychotherapy and cognitive behavioural therapy) and dermatological disorders such as acne vulgaris, atopic dermatitis, lichen planus, psoriasis, chronic urticaria and viral infections which includes facial/genital warts. This finding is corroborated by previous observations by Van Moffaert et al. (1992) and Cole et al. (1998). Patients that had the above skin disorders and were subjected to sessions of counselling at different times of their clinic/follow up 
visits had statistically significant reduction on their psychological distress as evidenced by the reduction in their mean scores in this study.

Ukonu et al in their study had shown a high psychiatric distress such as depression, anxiety among sufferers of atopic dermatitis and acne vulgaris in our environment (Ukonu \& Ezechukwu, 2012), and this is further buttressed by Papadopoulos et al (Papadoulos \& Walker, 2003). Hence, Ohya et al. suggested that a proper assessment of a patient's experience beyond the skin disorders helps to strengthen the Doctor-patient relationship which has been shown to be an integral part of adherence to the management of atopic dermatitis (Ohya et al., 2001).

It can be frustrating to live with chronic recurring and relapsing skin disorders for which we do not have a permanent cure. Even when there are multiple effective treatment means available, the clinical outcome relies heavily on the patient's level of compliance (Lavd, Webb, \& Thompson, 2012). We observed a differential compliance among female subjects towards psychological interventions as compared to their male counterpart.

This study showed that a higher percentage of the females came back for the second counselling session but during the third counselling session the percentage of males that complied were higher than that of their female counterpart. Previous studies have shown that there is a greater propensity among the male dermatology patients to develop secondary psychiatric complications (Folks \& Kinney, 1992; Shellow et al., 1994; Robinson, Rumsey, \& Partridge, 1996). It therefore posits that greater attention should be paid to male dermatological patients with a view of encouraging them and proper psychological evaluation and intervention (Robinson, Rumsey, \& Partridge, 1996; Seng \& Nee, 1997).

Educational degree helped in compliance to follow up visit among subjects who needed psychological intervention. However subjects with primary education were not too eager in showing up at the third session as there was no statistically significant difference in the mean score at the second and third session. This study noted that younger age group and single subjects were more of a compelling factor driving subjects to come for their clinic/counselling session.

Furthermore, positive correlation existed between dermatological conditions such as acne vulgaris, lichen planus, atopic dermatitis and the need for psychological intervention was observed among the subjects. This could probably be attributed to the fact that dermatological patients with such conditions suffer various degrees of anxiety and depression (Owoeye et al., 2007; Pullmood \& Rajagopalan, 1996; Gupta, 2003).

In conclusion, the relationship between skin dermatoses and psychological conditions are least understood. Our study showed that there is disparity in the means of those who came back for counselling session and those who did not come back. In order to manage these patients effectively, there is need for holistic approach both of the dermatological and psychological disorder a patient presents since these would help not only to improve clinic compliance but will reduce drug dependence and increase the capacity of the patient to cope with their difficulties and to become more emotionally balanced.

We assert that most skin dermatoses will have better outcome if proper psychological counselling becomes an integral part of their management.

\section{References}

Alebiosu C. O. (2002). Dermatology Consultation in Olabisi Onabanjo University Teaching Hospital, Sagamu. West African Journal of Medicine, 21(3), 249.

Awaritefe, A. A., \& Obiaya M. O. (1985). The Relationship Between the State-Trait Anxiety Inventory (STAI), MPI and Psychological Measures Under Threat and Non-threat Conditions. Nig J. of Psychol. Res., 1, 33-48.

Beck, A. (1993). Cognitive Therapy: Past, Present and Future. Journal of Consulting and Clinical Psychology, 61, 194-198. http://dx.doi.org/10.1037/0022-006X.61.2.194

Buljan, D., Buljan, M., \& Situm, M. (2005). Psychodermatology: A Brief Review for Clinicians. Psychiatric Danub, 17, 76-83.

Cole, W. C., Roth, H. L., \& Sachs L. B. (1998). Group Psychotherapy as an Aid in the Medical treatment of eczema. Journal of American Academy of Dermatology, 18(2), 286-291. http://dx.doi.org/10.1016/S0190-9622(88)70041-9

Ehler's A., Stangier U., \& Gieler U., (1995). Treatment of Atopic Dermatitis: A Comparison of Psychological Approaches to Relapsing Prevention. Journal of Consulting and Clinical Psychology, 63(4), 624-635. http://dx.doi.org/10.1037/0022-006X.63.4.624 
Folks, D. G., \& Kinney, F. C. (1992). The Role of Psychological Factors in Dermatologic Conditions. Psychosomatics, 33, 45-54. http://dx.doi.org/10.1016/S0033-3182(92)72020-9

Fortune, D. G., Richards, H. L., Main C. J., \& Griffiths, C. E. M. (2000). Pathological Worrying Illness Perceptions and Disease Severity In Patients With Psoriasis. British Journal of Health Psychology, 5, 71-82. http://dx.doi.org/10.1348/135910700168775

Gupta, M. A., \& Gupta, A. K. (2003). Psychiatric and Psycho social Co-morbidity in Patients with Dermatological Disorders: Epidemiology and Management. American Journal of Clinical Dermatology, 4, 833- 842. http://dx.doi.org/10.2165/00128071-200304120-00003

Higgins, E. M., \& Du Viver, A. W. (1994). Cutaneous Disease and Alcohol Misuse. British Medical Bulletin, 50, 85-98.

Kellett, S, \& Gilbert, P. (2001). Acne: A Biopsychological And Evolutionary Perspective With A Focus On Shame. British Journal of Health Psychology, 6, 1-24. http://dx.doi.org/10.1348/135910701169025

Koblenzer, C. S. (1983). Psychosomotic Concepts In Dermatology. Archives of Dermatology, 119, 501-502. http://dx.doi.org/10.1001/archderm.1983.01650300055017

Koo, J. Y. (1995). Psychodermatology: A Practical Manual for Clinicians: Cur. Prob. Dermatology, 6, 204-232. http://dx.doi.org/10.1016/S1040-0486(09)80012-4

Koo, J. Y., Shellow, W. V., \& Hallman, C. P., (1994). Alopecia Areata and Increased Prevalence of Psychiatric Disorders. International Journal of Dermatology, 33, 849-850. http://dx.doi.org/10.1111/j.1365-4362.1994.tb01018.x

Lavda, A., Webb, T., \& Thompson A. (2012). The Effectiveness of Psychological Interventions for Adults with Skin Conditions: A Meta-analysis. British Journal of Dermatology, 167, 970-979. http://dx.doi.org/10.1111/j.1365-2133.2012.11183.x

Ohya, Y., Williams, H., Steptoe, A., Saito, H., Iikkura, Y., \& Anderson, R. (2001). Psychosocial Factors and Adherence to Treatment Advice in Childhood Atopic Dermatitis. The Journal of Investigative Dermatology, 117, 852-857. http://dx.doi.org/10.1046/j.0022-202x.2001.01475.x

Owoeye, O. A., Aina, O. F., Omoluaibi, P. F., \& Olumide, Y. M. (2007). An Assessment of Emotional Pain among Subjects with Chronic Dermatological Problems in Lagos, Nigeria. International Journal of Psychiatry Medicine, 37(2), 129-138. http://dx.doi.org/10.2190/H275-837T-844P-030H

Papadopoulos, L., \& Bor, R. (1999a). Psychological Approaches to Dermatology. Leicester, UK, BPS

Papadopoulos, L., Borl R., \& Legg C. (1999b). Psychological Factors in Cutaneous disease: An Overview of Research. Psychology, Health \& Medicine, 4(2), 107-126. http://dx.doi.org/10.1080/135485099106261

Papadoulos, L., \& Walker, C. (2003). Understanding Skin Problems: Acne, Eczema, Psoriasis and Related Conditions. West Sussex.

Pullmood, S., \& Rajagopalan, B. (1996). Psychiatric Morbidity among Dermatology in Patients. The National Medical Journal of India, 9, 208-210.

Robinson, E., Rumsey, N., \& Partridge, J. (1996). An Evaluation of the Impact of Social Interaction Skills Training for facially Surgery Disfigured People. British of Plastic Surgery, 49, 281-289. http://dx.doi.org/10.1016/S0007-1226(96)90156-3

Seng, T. K., \& Nee, T. S. (1997). Group Therapy: A Useful and Supportive Treatment for Psoriasis Patients. International Journal of Dermatology, 36(2), 110-112. http://dx.doi.org/10.1046/j.1365-4362.1997.00011.x

Spielberger, C. D., Gorrsuch, R. L., \& Lushere, R. E. (1987). The State-Trait Anxiety Inventory. Palo Alto California Consulting Psychologist Pree.

Ukonu, A. B., \& Ezechukwu, A. (2012). Prevalence of Suicidal Ideation among Dermatological Outpatients. New Nigerian Journal of Clinical Research, 2(4), 300-308.

Van Moffaert, M. (1992). Psychodermatology: An Overview. Psychotherapy \& Psychosomatics, 58, 125-136. http://dx.doi.org/10.1159/000288621 


\section{Copyrights}

Copyright for this article is retained by the author(s), with first publication rights granted to the journal.

This is an open-access article distributed under the terms and conditions of the Creative Commons Attribution license (http://creativecommons.org/licenses/by/3.0/). 